文

1) 山田ほ加; 整形外科 $538,21,1970$.

2）吉川; 7 757, 21, 1970.

3）吉川; 災害外科 $258,12,1969$.

4）尖児ほ加; 臨整外 263, 1, 1966.

5) 真角ほ加; 整形外科 $508,18,1967$.

6) H. Jesserer; Osteomazie

7) C. E. Dent; J. B. J. S 266, 34-B, 1952.

質 問鹿大田中 源郎

1. 尿中カルシウム，無機燐の定量值とVHD の投 与との間に何らかの関連がみられるかどうか.

2.VHD の投与量をいかに決定されたか，VHD
中毒の予知はいかにしているか。

回 答指宿温泉中央病院 松田 秀雄

原田 正孝

Vitamin D の大量投与により中毒症を 起てすが， 血中 $\mathrm{Ca}$ が $11 \mathrm{mg} / \mathrm{dl}$ 以上に達すると中毒症を起こ すと言われているので, 血中 $\mathrm{Ca}$ 定量をしながら溸次 Vitamin D の量を増加しなければならないが，維持 量は個々によって違うので一応中毒量までもっていっ て Control すべきだと思う。

尿中 $\mathrm{Ca}, \mathrm{P}$ は最初は測定しえなかったが，最近測 定するととが出来たので, てれらを測定しながら治療 して行きたい。

副甲状腺機能䒕進症と疑われる一例

熊本大学整形外科学教室

伊 勢 紘 平・北 川 敏 夫
木 村 千 仍・忽那 龍 雄
永 吉 康 祐

\title{
A Case Report: Possible Hyperparathyroidism
}

By

\author{
K. Ise, T. Kutuna, T. Kitagawa, C. Kimura, \\ Y. Nagayoshi
}

Dep. of Orth. Sur. Kumamoto Univ. med. School

Patient: 51 years old female.

Chief complaints are polyarthralgies and pathological fracture of right upper extremity.

Family history: non contributely.

Past history: duodenal ulcer, bronchial asthoma.

Present history: She developed the pain and swelling of both hands, knees and elbows in Jan. 1971. At that time she noticed a loss of appetite and general weakness which were followed difficulty in walking and was hospitalized on Apr. 18, 1971 . On that day she developed a pathological fracture in her right humerus and was transferred to our hospital.

On X-Ray examination, right upper extremity showed abnormal findings which were polycystic and localized osteolytic changes.

On biopsy from her tibia, it was revealed histologically to be like a hyperparathyroidism. There may be some doubt to diagnose definitely as laboratory and physical examinations did not reveal typical findings related to hyperparathyroidism, however, this is a interesting case could be diagnosed as hyperparathyroidism. 
最近，我々は副甲状腺機能圥進症と疑われる一症例 を経験したのでここに報告する，症例は 51 才の主婦 で多関節痛及び病的骨折を主訴として来院した．家族 歴に異常はない，既往歴に十二指腸潰瘍（35才）及び 生来の気管支喘息がある. 現病歴は昭和 45 年 12 月ま で何らの愁訴なく日常生活に支障はなかった。昭和 46 年 1 月頃より両側の手関節, 时関節及び膝関節に 疼痛を覚え，某医にて RA の診断のもとに通院治療 を行なった。しかし次第に疼痛は増強し, 昭和 46 年 4 月には両膝痛のため，歩行不能となり同年 4 月 18 日に某病院に入院した。同日，右上脑部がベットのカ ドに当たり骨折を来たし，同部のレントゲン所見に て, 多発性かつ限局性, 囊腫状の異常陰影がられ, 病的骨折力疑われ本年 8 月 2 日に熊大病院整形外科汇 転院し，各種の対症療法にもかかわらず，本年10月 24 日に死亡した。

\section{入院時所見}

\section{（全身所見）}

体格：小, 栄養状態: 貧, 皮䖉: やや乾燥, 眼検結 膜: 慢性力夕ル性結膜炎有り, 耳: 慢性中耳炎, 菡 : 総義柬（㐘は 5 年前にすべて自然に拔けたとの事であ る.）肺：肺気腄有り.

\section{(局所所見)}

両上肢：骨折による変形が著明であり，運動痛あ り，また上腕部は浮腫が著明である。

両下肢：筋萎縮が著明で，浮腫が足関節部より足尖 までみられる。

両膝関節：著明な運動痛があり腫脹, 熱感発赤など は認められない。

\section{（レントゲン所見）（図 1)}

金椎を除く全骨に多発性でありしかも限局性, 囊腫 性の骨融解像を呈する.

\section{(生化学的検查)}

生化学的検查所見では血清 $\mathrm{Ca}$ 值は $6.7 \mathrm{mEq} / \mathrm{dl}$ とやや高值を呈し 無機燐は $2.7 \mathrm{mg} / \mathrm{dl}$ とやや低值を 示した. 総蛋白量は $5.7 \mathrm{~g} / \mathrm{dl}$ であり $\mathrm{Al}$ の減少と $r-$ グロブリンの増加を呈した．血沈值は 1 時間值 48, 2 時間值 75 , 中等值 43 とやや 元進し, CRP 反応H $\mathrm{RA}$ 反応斗となっている. また尿中の $\mathrm{Ca}$ 值は 0.7 $\mathrm{mEq} / \mathrm{dl}$, 無機燐は $20 \mathrm{mg} / \mathrm{dl}$ となっている. PSP 值 は 15 分值 $9.2 \%, 30$ 分值 $5.3 \%, 45$ 分值 $4.9 \%$, 120 分值は $7.0 \%$ となっており明らかな腎障害を呈し

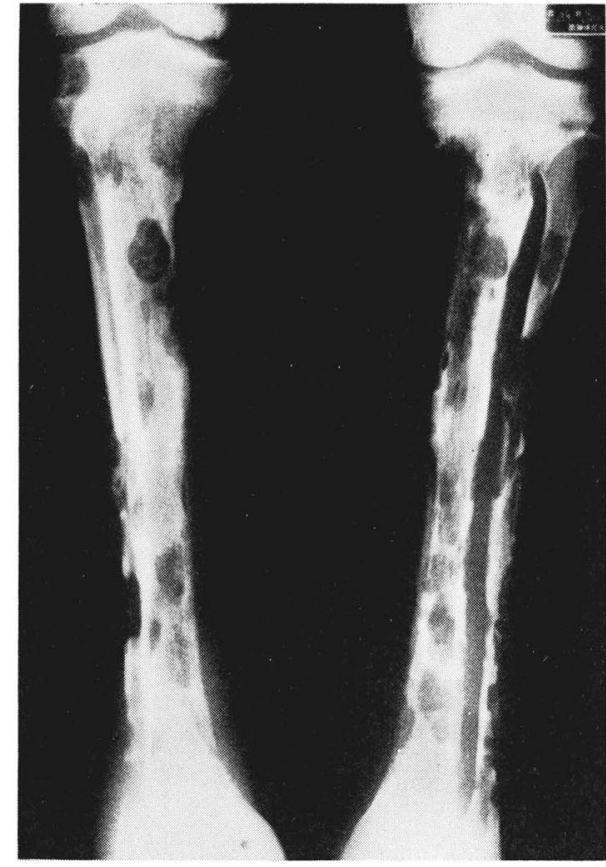

図 1 副甲状腺機能え進症と疑れる 1 例

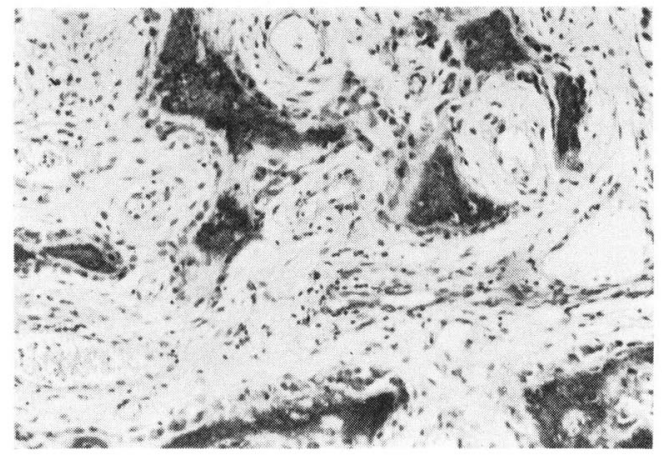

図 2 副甲状腺機能六進症と疑われる一例

た。

\section{（組織検査）（図 2）}

右脛骨部の組織生検を行なったところ, 進行性の骨 吸収と骨の線維組織化がみられ，また破骨紐胞及び巨 細胞がみられ汎発性線維性骨炎に類似した所見が得ら れた。

\section{剖 検 所 見}

（肉眼所見）

長管骨はその骨鹃植肪化し，レ線上透過像を示し た部分はその骨皮質の消失がみられた，胃及び十二指 


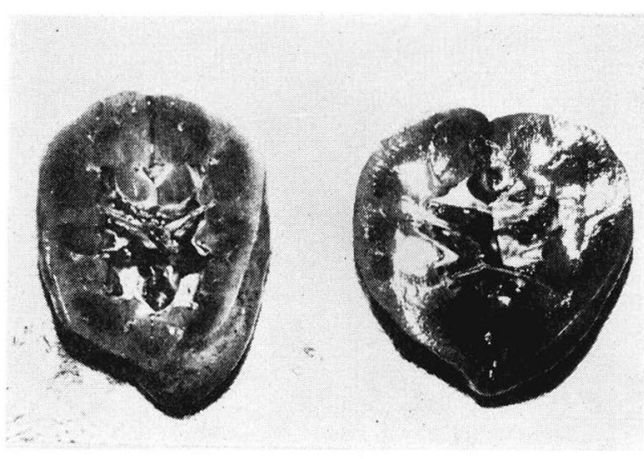

図3副甲状腺機能六進症と疑われる一例

腸には多数のビラン面がみられた。腎は両側共に石灰 沈着が著明であった（図 3 ）。 また副甲状腺腫は認め られていない.

\section{(顕微鏡所見)}

現在病理学教室にて検率中であり詳紐な結果は判明 していない.

$$
\text { 考察 }
$$

沉発性線維性骨炎は1891 年レックリング八ウゼン がその症例を報告して以来, 比較的多くの症例が報告 されている.その主なる症状としては, (1)骨変化, (2) 腎障青, (3)消化性漬痬, (4)膵炎, (5)易疲労性, (6)その 他高 $\mathrm{Ca}$ 血症によるもの，などが挙げられている.

骨変化はフリーデンベルグ等は, (1)骨粗荎症, (2)手 指骨，鎖骨及び脛骨の骨膜下吸収像，(3)全身性または 局所性の囊腫性変化, (4)関節周囲の石灰沈着像などが 本症に特有な所見であると述べている。本例に於いて は全身の骨に多発性, 限局性で囊腫性の変化を呈した のみであり, 関節周囲の石灰沈着像などはみられなか った。

腎障害については腎結石の問題がある．統計による とコープ等によれば 433 例中 $56.8 \%$ に見られたと述 べている．また腎結石は両側性で再発性の結石として 現われる事が多いと述べられている事は注意を要する ものと思われる．本例においては剖検により，両側性
に多数の小結石が認められた。

消化性潰瘍としては, 統計によると大部分が十二指 腸潰瘍であり，胃漬瘍は全体の $1 / 5$ 程度であると述べ られている．本例に於いても十二指腸潰瘍の存在が指 摘されており，また剖検により多数のビラン面が確認 された。

その他高 $\mathrm{Ca}$ 血症による症状として嘔吐, 下痢など の腹部症状があげられている．本例に於いても入院前 及び入院期間中に湢吐あるいは下痢あるいは便秘等, 種々の腹部症状を呈した。

本症に特徴のある $\mathrm{Ca}$, 無機燐の変動については, (1)血液中の $\mathrm{Ca}$ 值の増加, 無機燐值の低下, (2)尿中 の $\mathrm{Ca}$, 及び無機燐の排泄増加, (3)\% TRP の低下, (4) $\mathrm{Ca}$ 急速負荷による尿中無機燐の増加及び $\mathrm{Ca}$ に対 する反応の欠如などがあげられている．本例に於いて は(1)及び(3)の検査結果は陽性所見を呈したが，(2)及び (4)の検査結果は陽性所見を得られなかった．我々はこ の事は高度の腎障害によるものと考えている。

\section{結瑟}

以上のような検査所見ならびにレントゲン所見より 我々は，1. 副甲状腺機能六進症， 2 . アルブライト 症候群，3. ページェット病，4. 多発性骨髄腫， 5 . 悪性腫瘍の骨転移等を考え, 副甲状腺機能九進症 による骨変化を最も強く疑った。しかしながら本例に おいては，検査所見並びに臨床所見になお副甲状腺機 能六進症と断定するには問題があり，諸兄の御批判並 びに御教示が頂ければ幸いである。なお剖検所見の詳 細については現在検討中である.

質 問鳥取大 前山篇 腎障害から続発したものとお考えでしょうか.

回 答熊大整形 伊勢 紘平

高度の腎障害より，続発性のものも考えている。な お詳細については剖検にて検討中であります. 